\title{
Publisher's Note: Journal of Health, Population and Nutrition, volumes published in 2015
}

Journal of Health, Population and Nutrition

Due to a technical error in production, between June 2015 and December 2015, articles that should have been published in Volume 34 were published in Volume 33 giving the impression of a gap in volumes between Volume 33 (2015) and Volume 35 (2016). We apologise for any confusion caused to our readers.

Published online: 04 April 2016

Submit your next manuscript to BioMed Central and we will help you at every step:

- We accept pre-submission inquiries

- Our selector tool helps you to find the most relevant journal

- We provide round the clock customer support

- Convenient online submission

- Thorough peer review

- Inclusion in PubMed and all major indexing services

- Maximum visibility for your research

Submit your manuscript at

www.biomedcentral.com/submit 